ДВІГУН А.O. ${ }^{*}$

1* доктор економічних наук, професор, головний консультант центру регіональних досліджень, Національний інститут стратегічних досліджень, е-mail: dvigun.alla@gmail.com, ORCID ID:0000-0002-01688682

\title{
ПРОБЛЕМИ ТА ПЕРСПЕКТИВИ РОЗВИТКУ ОСВІТИ ЯК ЧИННИКИ СТАЛОГО РОЗВИТКУ ГРОМАД
}

У статті досліджено питання впровадження освітньої реформи в умовах децентралізації та реформування адміністративно -територіального устрою в Україні. Дана оцінка тенденцій розвитку освіти та процесам секторальної децентралізації у сфері освіти, виокремлено сучасні проблеми, які постали в управлінні освітньою галуззю після завершення першого етапу адміністративно-територіальної реформи в Україні, визначено роль місцевих органів управління освітою в умовах децентралізації. У статті окреслено напрями та шляхи вирішення проблем у подальшому розвитку галузей освіти, як впливого чинника сталого розвитку територій. Мета. Дослідити основні тенденції розвитку освіти в умовах її реформування та децентралізації, запропонувати шляхи вирішення сучасних проблем, що сформувалися в освітніх галузях. Методика. У процесі дослідження використано емпірично- теоретичний метод, заснований на аналізі статистичних даних, синтезі соціально-економічного стану територіального розвитку та розвитку громад, структурний метод; порівняльного аналізу; абстрактно-логічного узагальнення. Наукова новизна. Дослідження та отримані наукові результати присвячені новітнім тенденціям розвитку освітніх галузей в умовах впровадження в України наступного етапу адміністративно-територіальної реформи. Результати. Запропоновані у досліджені рекомендації можуть бути використані органами держаної та місцевої влади.

Ключові слова: децентралізація, адміністративно-територіальний устрій, сталий розвиток, освіта, освітня система, реформування системи освіти.

\section{Постановка проблеми}

В Меті та стратегічних цілях Державної стратегії регіонального розвитку на 2021-2027 роки зроблено акцент на тому, що розвиток та єдність, орієнтовані на людину, повинні бути реалізовані в децентралізованій Україні 3 ефективним багаторівневим врядуванням. Тобто невід'ємною частиною державної регіональної політики та регіонального розвитку в Україні $є$ ефективність процесів децентралізації та реформування адміністративно-територіального устрою. Децентралізація формує потенційні інструменти здійснення більш ефективної політики розвитку регіонів та громад завдяки спроможності, в повній мірі охоплювати та оптимально залучати в економічний оборот місцеві ресурси, забезпечувати гнучкість та адресність підходів до мотивації територіального розвитку. Тобто децентралізація є ефективним інструментом стимулювання соціально-економічного розвитку територій. Скаладовою частиною процесів децентралізації $є$ секторальна децентралізація, в освіті тощо.
Освіта відіграє надзвичайно важливу роль у формуванні громадянського суспільства i розвитку країни в цілому. У 2017 році був прийнятий новий Закон України «Про освіту», який заклав концептуальні принципи подальшого реформування освітніх галузей. Цей закон $\epsilon$ рамковим і служить підгрунтям для ухвалення законів «Про дошкільну освіту», «Про загальну середню освіту», «Про позашкільну освіту», «Про професійну освіту», «Про освіту дорослих», зміни до закону «Про вищу освіту» [15]. Законодавчо закріплені різні варіанти здобуття освіти: дистанційно, індивідуально (екстернат, сімейна освіта). Вперше заговорили про індивідуальну освітню траєкторію та компетентісний підхід у навчанні.

Реформа в освіті та реформа адміністративно-територіального устрою мають безпосередній зв'язок та взаємний вплив. Управління освіти на територіальному рівні втратили свої контролюючі функції, а директора школи обирає конкурсна комісія. Значно розширено автономію закладів освіти, а функції управлінь освітою 3 керування 
закладами освіти змінюються на функції та завдання щодо розробки i забезпечення реалізації державної політики у галузі освіти, збір та обробку статистичних даних, підготовку прогнозів 3 питань розвитку освіти. Основний спектр повноважень управління освітою надано місцевим радам, тому 3 метою забезпечення громадян, що проживають на відповідних територіях, гарантованим Коституцією правом на освіту, місцеві ради мають створити самостійні підрозділи задля виконання управлінських функцій засновників закладів освіти.

\section{Аналіз останніх досліджень та публікацій}

Питанням досліджень децентралізації та секторальній децентралізації присвячено чимало праць відомих вчених: I. Дьоміна [1] Б.Данилишин [3], 3. Варналій [2], Я. Жаліло [5], О. Дем'янчук [4], I Сторонянська [4], О.Шевченко [6], Морган [14], Харбергер [13].

\section{Виклад основного матеріалу дослідження}

Потужну державу і конкурентну економіку може забезпечити згуртована спільнота творчих людей, відповідальних громадян, активних i підприємливих. Саме таких громадян мають готувати заклади освіти. Зміст професійної (професійно-технічної), фахової передвищої та вищої освіти має постійно оновлюватися з урахуванням потреб ринку праці. Особливої актуальності набуває питання мобільності, конкурентоспроможності та рівня кваліфікації працівників.

Державна політика у сфері освіти і науки відіграє вирішальну роль у забезпеченні розвитку людського капіталу та отриманні економічної вигоди у вигляді сталого зростання й конкурентної економіки, а значить суспільного та індивідуального добробуту, майбутнього процвітання та якості життя. Досягнення цих цілей потребує узгоджених політичних ініціатив, ефективних управлінських рішень та довгострокових інвестицій [1].

Очевидно, що сьогодні українська освіта не відповідає ані сучасним запитам з боку особистості та суспільства, ані потребам економіки, ані світовим тенденціям [17]. Саме тому здійснюється системна трансформація сфери для забезпечення нової якості освіти на всіх рівнях: від дошкільної освіти - до вищої освіти та освіти дорослих.
Вже сьогодні необхідно здійснювати низку заходів щодо вирішення нагальних освітніх питань та уникнення глибокої освітньої кризи через пандемію COVID-19 в умовах загострення економічної та соціальної нерівності [1].

Освітня реформа в Україні здійснюється за такими пріоритетними напрямами:

•доступна та якісна дошкільна освіта;

•«Нова українська школа»;

- сучасна професійна освіта;

•якісна вища освіта та розвиток освіти дорослих;

•розвиток науки та інновацій.

За кожним напрямом сформовано завдання, спрямовані на досягнення спільної мети: перетворення української освіти на інноваційне середовище, в якому учні й студенти набувають ключових компетентностей, необхідних кожній сучасній людині для успішної життєдіяльності, а науковці мають можливості та ресурси для проведення досліджень, що безпосередньо впливатимуть на соціально-економічний та інноваційний розвиток держави.

На шляху реформування освіти, державою та місцевими органами здійснюються послідовні кроки, серед яких:

1. У сфері дошкільної освіти: розвиток мережі закладів дошкільної освіти різних типів та форм власності; оновлення змісту дошкільної освіти для забезпечення наступності між дошкільною та початковою освітою; упровадження сучасних освітніх методик та технологій в освітній процес ЗДО; створення сучасного, безпечного та комфортного освітнього середовища; створення умов для навчання дітей 3 особливими освітніми потребами в закладах дошкільної освіти починаючи 32 років; створення системи забезпечення якості дошкільної освіти.

2. У сфері повної загальної середної освіти: затверджена концепція «Нова українська школа» на 2017- 2029 роки, яка передбачає проведення докорінної та системної реформи загальної середньої освіти, зокрема змісту, педагогіки, системи управління, системи державного фінансування, нормативно-правового забезпечення освітньої галузі; з 2020 року обсяг освітньої субвенції 3 державного бюджету місцевим бюджетам розраховується на основі реального контингенту учнів, що 
збільшило спроможність місцевих бюджетів для встановлення надбавок та доплат педагогам у максимальному розмірі; запроваджено цільові субвенції для покращення матеріально-технічного стану шкіл, субвенція "Спроможна школа" та субвенція на STEM освіту; сформовано мережу опорних шкіл (станом на початок 2021 року в Україні функціонують 1033 опорні школи та 1540 філій, в яких навчається майже 475 тис. учнів, забезпечено підвезення майже 80 тис. учнів до закладів освіти та у зворотному напрямку); за останні п'ять років кількість учнів 3 особливими освітніми потребами, які навчаються в інклюзивних класах закладів ЗСО зросла у 7,1 рази; кількість інклюзивних класів зросла в 5 разів та в 3,7 стало більше шкіл, в яких облаштовані такі класи, інклюзивне навчання відбувається $\quad$ у $35 \%$ закладів загальної середньої освіти; сформовано мережу з 610 інклюзивно-ресурсних центрів та 25 ресурсних центрів підтримки інклюзивної освіти в усіх областях України.

Реформування освіти невід'ємно пов'язане 3 адміністративно-територіальною реформою та процесами децентралізації, започаткованими у 2014 році з прийняттям Концепції реформи місцевого самоврядування та територіальної організації влади, Законів «Про співробітництво територіальних громад», «Про добровільне об'єднання територіальних громад》 та змін до Бюджетного і Податкового кодексів - щодо фінансової децентралізації. Після місцевих виборів 25 жовтня 2020 року [9] утворилися i розпочали роботу територіальні громади, які тепер відповідатимуть за забезпечення законних прав та інтересів громадян, що проживають на їхній території, у всіх сферах суспільного життя, у сфері освіти тощо. Органам місцевого самоврядування усіх громад разом 3 отриманням бюджетних преференцій та управлінських повноважень необхідно буде взяти на себе складне завдання та відповідальність за створення ефективного управління системою освіти, у т.ч створення самостійних підрозділів щодо виконання управлінських функцій засновників закладів освіти. Ці процеси строго індивідуальні в кожній громаді, оскільки не існує двох повністю однакових громад. Також найважливішим кроком розвитку освіти $\epsilon$ впровадження моделі «Нова українська школа» [16]. Поняття «Нової школи» розкривається на основі формули, яка включає вісім компонентів: новий зміст освіти, заснований на формуванні компетентностей, необхідних для успішної самореалізації в суспільстві; умотивований учитель, який має свободу творчості й розвивається професійно; наскрізний процес виховання, який формує цінності; децентралізація та ефективне управління, що надасть школі реальну автономію; педагогіка, що грунтується на партнерстві між учнем, учителем і батьками; орієнтація на потреби учня в освітньому процесі, дитиноцентризм; нова структура школи, яка дозволяє добре засвоїти новий зміст і набути компетентності для життя; справедливий розподіл публічних коштів, який забезпечує рівний доступ усіх дітей до якісної освіти. Вищеперераховані компоненти нової моделі української школи, запропоновані Міністерством освіти і науки України та положеннями нового Закону України «Про освіту» [15], мають стати стратегічною основою для розвитку системи освіти в об'єднаних громадах, яка охопить не тільки навчально-виховний процес, а й управління всією освітньою мережею громади (тобто наскрізними завданнями в діяльності органу управління освітою стануть, зокрема, реалізація плану оптимізації шкільної мережі, інноваційної педагогічної діяльності

Сучасними проблемами, які постали в управлінні освітньою галуззю після завершення першого етапу адміністративнотериторіальної реформи в Україні $є$ такі:

1) нерівномірний розподіл освітніх закладів, які раніше перебували у спільній власності територіальних громад міст, сіл та селищ, особливо це стосується закладів позашкільної освіти, спортивних шкіл, закладів інклюзивної освіти, інклюзивноресурсних центрів, міжшкільних навчальновиробничих закладів;

2) значна кількість малокомплектих закладів, які відтягують на себе значний бюджетний ресурс, кількість учнів у яких має негативну стабільну тенденцію до зменшення;

3) недостатня керованість системи освіти в умовах запровадження нового освітнього законодавства та адміністративнотериторіального поділу;

4) порівняно невелика заробітна плата спричиняє відтік молодих спеціалістів; 
5) низький соціальний статус педагогічних працівників, а відтак відсутність внутрішньої мотивації педагогічних працівників та керівників закладів освіти до професійного розвитку; неготовність педагогів та керівників закладів працювати в умовах автономії та академічної свободи;

6) значна частина педагогічних працівників поки що не має навичок ефективного використання інформаційно-комунікаційних та цифрових технологій, проєктної діяльності;

7) сьогодні дошкільна та шкільна освіта повністю фінансується з місцевих бюджетів і є заручником доходів громад, певна кількість яких має обмежені можливості для забезпечення достатнього фінансування, в основному через низьку фінансову спроможність;

8) повільно відбувається перехід на фінансову автономію закладів освіти;

9) кількість місць в дошкільних закладах та закладах загальної середньої освіти не відповідає потребам, насамперед потребам міських громад, а в сільській місцевості спостерігається низьке охоплення дітей дошкільною освітою;

10) суттєві територіальні відмінності в якості освіти та, відповідно, результатах навчання;

11) відсутність програм та навчальнометодичних матеріалів для дистанційного та змішаного навчання;

12) нестача коштів у бюджетах територіальних громад на забезпечення безпечних та нешкідливих умов освіти, зокрема на протипожежні заходи (встановлення протипожежної сигналізації, обробки горищ, встановлення блискавкозахисту тощо);

13) інституційна нерозвинутість мережі центрів професійного розвитку педагогічних працівників, що ускладнює педагогам вибір потрібних їм послуг;

14) відсутність у більшості керівників 33СО та педагогічних працівників досвіду стратегічного планування освітнього процесу;

15) відсутність системи навчання дорослих «освіта протягом життя»

\section{Висновки}

Незважаючи на ряд проблем, освітня сфера - це один із найкращих прикладів децентралізації, яка дала поштовх стрімкому розвитку громад. У рамках цих змін перед територіальними громадами постає багато завдань, в тому числі створення ефективного управління освітою на місцях, яке б могло задовольнити освітні потреби учнів на високому рівні. Освіта - це ключовий сегмент, який визначає рівень розвитку громади, регіону, і країни в цілому, адже якісне навчання сприяе формуванню освіченого суспільства та висококваліфікованих кадрів. Освіта є однією 3 передумов досягнення сталого розвитку i найважливішим інструментом ефективного управління та обгрунтованого прийняття рішень [19]. Для розв'язання численних проблем сталого розвитку громад та регіонів будуть потрібні нові знання, уміння та компетентності, необхідні для глибокого розуміння складних проблем i вирішення взаємопов'язаних питань суспільного життя. На нашу думку першочерговими кроками для подальшого впровадження такої системи $є$ :

1) удосконалення законодавства у сфері дошкільної освіти: прийняття Закону України «Про дошкільну освіту» (нова редакція); внесення змін до Положення про дошкільний навчальний заклад;

2) проведення оцінки якості дошкільної освіти за шкалами дослідження ECERS (Early Childhood Environment Rating Scale);

3) розробка та впровадження державної програми навчання керівників закладів освіти основам фінансового менеджменту й управління;

4) 3 метою вирішення проблеми нестачі коштів для модернізації харчоблоків закладів освіти, для запровадження у закладах освіти системи управління безпечністю харчування необхідно розробити та впровадити державну програму забезпечення переобладнання харчоблоків закладів освіти згідно з вимогами системи впровадження постійно діючих процедур, заснованих на принципах системи аналізу небезпечних факторів та контролю у критичних точках (НАССР);

5) 3 метою вирішення проблеми нестачі коштів у бюджетах територіальних громад на забезпечення безпечних та нешкідливих умов освіти, зокрема на протипожежні заходи (встановлення протипожежної сигналізації, обробки горищ, встановлення блискавкозахисту то що) необхідно розробити та впровадити відповідну Програму на рівні КМУ із виділенням щорічного цільового фінансування на здійснення заходів 3 
протипожежного захисту на умовах співфінансування із місцевими бюджетами;

6) створення мережі центрів професійного розвитку педагогічних працівників; запровадження педагогічної інтернатури та впровадження державної програми методичної допомоги, в тому числі й координації подальших дій центрів;

7) розроблення та затвердження Дорожньої карти впровадження профільної освіти;

8) розроблення та впровадження нової моделі державної системи оплати праці в закладах освіти;

9) впровадження механізмів забезпечення фінансової автономії закладів освіти для здійснення своєї діяльності;

10) дерегуляція ліцензійних умов та запровадження електронного ліцензування діяльності у сфері освіти;

11) запуск електронної системи моніторингу працевлаштування випускників закладів вищої та професійної освіти;

12) розроблення та впровадження проекту Положення про дуальну форму здобуття вищої освіти.

\section{DVIHUN ALLA ${ }^{1 *}$}

$1 *$ Doctor of Economic Sciences, Full Professor, chief consultant Sector of Regional Strategies Center for Regional Studies, The National Institute for Strategic Studies, e-mail: dvigun.alla@ gmail.com,ORCID ID:0000-0002-01688682

\section{PROBLEMS AND PROSPECTS OF EDUCATION DEVELOPMENT AS FACTORS OF SUSTAINABLE DEVELOPMENT OF COMMUNITIES}

The article examines the issues of implementation of educational reform in the context of decentralization and reform of the administrative-territorial structure in Ukraine. An assessment of the trends in the development of education and the processes of sectoral decentralization in the field of education is given, the current problems in the management of the educational sector after the completion of the first stage of the administrative-territorial reform in Ukraine are highlighted, the role of local educational authorities in the context of decentralization is determined. The article outlines the directions and ways of solving the problems of the further development of the branches of education, as an influential factor in the sustainable development of territories.

Keywords: decentralization, administrative-territorial structure, sustainable development, education, educational system, reforming the education system.

\section{REFERENCES}

1. Dyomina IO Public-private partnership as a mechanism for the development of education in Ukraine in the context of decentralization and globalization. / Scientific Notes Volume 32 (71) № 2- 2021 - P.52-58

2. Varnaliy ZS The impact of tax holidays on the competitiveness of the national economy: world experience and Ukraine / Theoretical and applied issues of the economy. Vip. 23

URL: http://archive.nbuv.gov.ua/portal/soc_gum/tppe/2010_23/Zb23_02.pdf.

3. Danylyshyn BM Decentralization in EU countries: lessons for Ukraine // Regional Economy. No 1. 2016. S. 5-14. 4. Demyanchuk OI Decentralization of financial resources by local budgets of Ukraine / OI Demyanchuk // Scientific notes of NU "Ostroh Academy"; Nat. Ostroh Academy University. Ostrog, 2013. Vip. 21. - P. $139-143$. 
5. Zhalilo Ya.A., Dvigun AO, Shevchenko OV etc..Decentralization of power: the order of the medium term: an analytical report / ed .. Zhalilo Ya.A.-K: NISS, 2019. -192 p.

6. Dvigun AO, Shevchenko OV etc. Decentralization and formation of regional development policy in Ukraine: science. ext. / Engine AO, Shevchenko OV, etc.]; for science. ed. Dr. Econ. Sciences Ya. A. Zhalila. Kyiv: NISS, 2020. 153 p.

7. Ministry of Development of Communities and Territories of Ukraine. URL: https://www.minregion.gov.ua/napryamki-diyalnosti/regional-dev/derzhavna-rehional-napolityka/monitorynh/monitorynh-monitorynh/reytingova-otsinka-regioniv/analiz-soczialno-ekonomichnogo-rozvy/ 8. Nudelman VI Why do we need general plans of territories? January 7, 2017 // Ukrainian Pravda URL: http://www.pravda.com.ua/columns/2017/01/7/71315789

9. CEC Resolution No. 176 of August 14, 2020, On Calling the First Elections of District Council Deputies to October 25, 2020 https://act.cvk.gov.ua/acts/pro-priznachennya-pershih-viboriv-deputativ-rayonnih- rad-na-25zhovtnya-2020-roku.html

11. Website of the Association of Ukrainian Cities. Sectoral dialogue URL: https://auc.org.ua/sector-news/188

12. OECD (2019), Making Decentralization Work: A Handbook for Policy-Makers, OECD Multi-level Governance Studies, OECD Publishing, Paris. URL: https://doi.org/

13. 1787 / g2g9faa7-en.12.Harberger A.C. Taxation and welfare. / A.C. Harberger. Michigan: Little, Brown, 1974. $304 \mathrm{p}$.

14. Morgan, K. (2006), "Devolution and development: Territorial justice and the north-south divide", Publius, Vol. 36/1, pp. 189-206. URL: http://www.jstor.org/stable/20184949

15. On education: Law of Ukraine of 05.09.2017 № 2145-VIII. Information of the Verkhovna Rada of Ukraine. 2017. № 38-39. St. 5

16. Dotsenko-Belous N. Sectoral review in the field of educational services. USAID, 2015. URL: http://pppukraine.org/wp-content/uploads/2015/12/Education-Sector-Brief-UKR.pdf.

17. Education in Ukraine: challenges and prospects / Information-analytical collection-Institute of Educational Analytics, Ministry of Education and Science of Ukraine. Kyiv, 2020.

URL: https://iea.gov.ua/wp-content/ uploads / 2020/08 / Informatsijno-analitichnij-zbirnik-Osvita-v-Ukrayinivikliki-ta-perspektivi.pdf? Fbclid = IwAR2 RU8yLeHjNIhP8CVgDu5YEeaBxlj

18. Sustainable development of local communities in terms of decentralization: monograph / Ortina GV, Sokil OG, Prus YO, Zastrozhnikova IV, Efimenko LM - Melitopol: FOP Odnorog TV, 2019. - 171 p.

19. On the Strategy of Sustainable Development of Ukraine until 2030. Law of Ukraine of 30.09.2019 № $722 / 2019$

URL: https://ips.ligazakon.net/document/JH6YF00A?an=332

Стаття надійшла до редакції: 8.06.2021

Received: 2021.06.80 